\title{
Epidermal Growth Factor Induces Phosphorylation of Extracellular Signal-Regulated Kinase 2 via Multiple Pathways
}

\author{
BOUDEWIJN M. T. BURGERING, ${ }^{1}$ ALIDA M. M. DE VRIES-SMITS, ${ }^{1}$ RENÉ H. MEDEMA, ${ }^{1}$ \\ PASCALE C. VAN WEEREN, ${ }^{1}$ LEON G. J. TERTOOLEN, ${ }^{2}$ AND JOHANNES L. BOS ${ }^{1 *}$ \\ Laboratory of Physiological Chemistry, Utrecht University, Vondellaan 24A, 3521 GG Utrecht, ${ }^{1}$ \\ and Hubrecht Laboratory, Utrecht, ${ }^{2}$ The Netherlands
}

Received 29 June 1993/Returned for modification 10 August 1993/Accepted 2 September 1993

\begin{abstract}
Expression of p21 rasAsn-17, a dominant negative mutant of $\mathbf{p 2 1}^{\text {ras }}$ that blocks p21 ${ }^{\text {ras }}$ activation by growth factors, inhibits activation of extracellular signal-regulated kinase 2 (ERK2) by insulin and platelet-derived growth factor in rat-1 cells [A. M. M. de Vries-Smits, B. M. T. Burgering, S. J. Leevers, C. J. Marshall, and J. L. Bos, Nature (London) 357:602-604, 1992]. Here we report that expression of p21 ${ }^{\text {rasAsn-17 }}$ does not abolish epidermal growth factor (EGF)-induced phosphorylation of ERK2 in fibroblasts. Since EGF activates p21 ${ }^{\text {ras }}$ in these cells, this indicates that EGF induces a p21 ras -independent pathway for the phosphorylation of ERK2 as well. We investigated whether activation of protein kinase $C$ (PKC) or increase in intracellular calcium could be involved in p21 $^{\text {ras }}$-independent signaling. In rat-1 cells, inhibition of either PKC, by prolonged 12- $O$. tetradecanoylphorbol-13-acetate (TPA) pretreatment, or calcium influx, by ethylene glycol-bis( $\beta$-aminoethyl ether)- $N, N, N^{\prime}, N^{\prime}$-tetraacetic acid (EGTA) pretreatment, did not abolish EGF-induced ERK2 phosphorylation. However, a combined inhibition of both $\mathbf{p 2 1}^{\text {ras }}$ and calcium influx, but not PKC, resulted in a complete inhibition of EGF-induced ERK2 phosphorylation. In contrast, in Swiss $3 T 3$ cells, inhibition of both p21 activation and TPA-sensitive PKC, but not calcium influx, inhibited EGF-induced ERK2 phosphorylation. These results demonstrate that in fibroblasts, EGF induces alternative pathways of ERK2 phosphorylation in a cell-type-specific manner.
\end{abstract}

Activation of transmembrane signaling receptors by first messengers generates the formation of second messengers. These second messengers are implicated in the induction of a myriad of intracellular signals of various biochemical constitutions. A common factor of signaling by many mitogenic stimuli is the activation of microtubule-associated protein 2 (MAP2) kinase (for recent reviews, see references 10,40 , and 42). Two forms of MAP2 kinase have been purified from fibroblasts with apparent molecular weights of 42 and $44 \mathrm{kDa}$. The $\mathrm{p} 42^{\mathrm{MAPK}}$ and $\mathrm{p} 44^{\mathrm{MAPK}}$ have been cloned and are also named, respectively, extracellular signal-regulated kinase 2 (ERK2) and 1 (ERK1), to reflect the diversity of signals that can regulate them (3). Activation of both ERK1 and ERK2 requires phosphorylation at neighboring threonine and tyrosine residues and dephosphorylation of activated ERK2 by serine/threonine phosphatases or tyrosine phosphatases results in inactive $\operatorname{ERK} 2(1,16)$. For ERK2, the sites of phosphorylation are located within one tryptic peptide and have been assigned to Thr-183 and Tyr-185 (35).

Since full activation of ERK2 requires both threonine and tyrosine phosphorylation, it has been suggested that integration of two signaling pathways is required for the activation of the kinase (1). However, it is now clear that ERK2 is part of a kinase/phosphatase cascade in which at least several serine/threonine kinases act upstream of ERK2. The MAP kinase kinase (MAPKK or MEK) that activates ERK2 and phosphorylates the threonine and tyrosine site of ERK2 has recently been cloned by several groups $(11,23)$. MAPKK activity itself is lost upon treatment with protein phos-

\footnotetext{
* Corresponding author.
}

phatase $2 \mathrm{~A}$ but not following treatment with phosphotyrosine phosphatases (13). This suggests that receptors do not directly activate the MAPKK, and indeed putative MAPKK kinases have recently been identified. One of these (denoted as MEKK) has been implicated in conveying signals from serpentine receptors (26), whereas another, the Raf- 1 kinase, is implicated in mediating signals from receptor tyrosine kinases towards ERK2 $(17,24)$. Raf-1 kinase acts downstream of $\mathrm{p}^{2} 1^{\text {ras }}$ in mitogenic signaling $(22,38)$, and recent experiments show that in vitro Raf-1 kinase binds $\mathrm{p} 21^{\text {ras }}$ in a GTP-dependent manner $(31,44,46)$. Also, at least in yeast cells, Raf-1 kinase and p21 ras are capable of interacting in vivo (46). We and others have shown that activation of $\mathrm{p} 21^{\text {ras }}$ is essential for the induction of ERK2 activity by insulin and platelet-derived growth factor (PDGF) in rat-1 fibroblasts and for ERK2 and Raf-1 kinase activity by nerve growth factor (NGF) and epidermal growth factor (EGF) in PC12 cells $(12,43,45)$. This suggests a model in which receptor tyrosine kinases are coupled to the Raf-1/ERK2 kinase cascade by a nonkinase and nonphosphatase intermediate, e.g., p21 $1^{\text {ras }}$.

In this study we have investigated whether in fibroblasts receptor tyrosine kinases couple to ERK2 exclusively via p21 ras activation. In our previous study we showed that protein kinase $\mathrm{C}(\mathrm{PKC})$ activation induces ERK2 activity by a p21 ${ }^{\text {ras }}$-independent mechanism, indicating that at least two different pathways for ERK2 activation exist (12). Since growth factors like EGF and PDGF can stimulate PKC activity, the question is whether these growth factors indeed employ redundant signaling pathways towards ERK2. Here we demonstrate that independent pathways to regulate ERK2 activity coexist within one cell type, that the nature of these pathways is cell type specific, and that, depending on 
the cell type, a stimulus can employ different combinations of these pathways.

\section{MATERIALS AND METHODS}

Materials and cell culture. Phosphate-free Dulbecco modified Eagle medium (DMEM), insulin, and EGF were obtained from Sigma. ${ }^{32} \mathrm{P}_{\mathrm{i}}(3,000 \mathrm{Ci} / \mathrm{mmol})$ was from Amersham, PDGF-BB homodimer was from AMGEN, and NGF, ionomycin $\left(\mathrm{Ca}^{2+}\right.$ ionophore $)$, and indo-1/AM $\{1$-[2-amino-5(6-carboxyindol-2-yl)phenoxy]-2-(2'-amino-5'-methylphenoxy) ethane- $N, N, N^{\prime}, N^{\prime}$-tetraacetic acid, pentaacetoxymethyl ester\} were from Boehringer Mannheim.

Rat-1, A14, and Swiss 3T3 cells were routinely grown in DMEM-10\% fetal calf serum (FCS) $-0.05 \%$ glutamine. PC12 cells were grown in DMEM (high glucose)-10\% FCS (heat inactivated)-5\% horse serum. For growth factor stimulation experiments, subconfluent cultures of cells were grown in DMEM-0.5\% FCS (PC12 cells in DMEM [high glucose]$0.5 \%$ horse serum) for $18 \mathrm{~h}$ prior to stimulation with growth factors.

GTP and GDP binding to p21 $^{\text {ras }}$. Serum-arrested cell cultures were washed two times with phosphate-free DMEM and labeled with $100 \mu \mathrm{Ci}$ of ${ }^{32} \mathrm{P}_{\mathrm{i}}$ per $\mathrm{ml}$ for $4 \mathrm{~h}$. After growth factor stimulation, cells were lysed and processed as previously described (7). Mature p21 $1^{\text {ras }}$ was separated from nonprocessed $\mathrm{p}^{2} 1^{\text {ras }}$ by a Triton X-114 phase split as described elsewhere $(7,15)$. p21 ras was precipitated from the detergent phase with monoclonal antibody Y13-259. As a control, immunoprecipitation with a nonrelated antibody directed against simian virus 40 large T (KT3) was used. Bound nucleotides were eluted from immunoprecipitates and analyzed by ascending thin-layer chromatography (TLC) as described elsewhere (7), and after exposure to Kodak XAR film spots corresponding to GDP and GTP were cut out. The amount of radioactivity (in counts per minute) was determined by liquid scintillation counting.

Determination of ERK2 phosphorylation and activity. Cells were lysed and $100 \mu \mathrm{g}$ of protein was immunoprecipitated with a polyclonal rabbit antiserum (anti-ERK2) directed against bacterially produced, near-full-length ERK2 (a gift from Chris Marshall, London, England). The immune complexes were collected by using protein A-Sepharose beads, washed, and incubated in a volume of $30 \mu \mathrm{l}$ with $0.4 \mu \mathrm{Ci}$ of $\left[\gamma^{-32} \mathrm{P}\right] A T P$ in $30 \mathrm{mM}$ Tris (pH 8.0), $20 \mathrm{mM} \mathrm{MgCl} 2,2 \mathrm{mM}$ $\mathrm{MnCl}_{2}$, and $10 \mu \mathrm{M} \mathrm{ATP}$ for $30 \mathrm{~min}$ with $7.5 \mu \mathrm{g}$ of myelin basic protein as a substrate. The mixture was electrophoresed on a $15 \%$ polyacrylamide gel, blotted to nitrocellulose, and autoradiographed. The labeled protein was counted by scintillation counting. To measure the mobility shift of the ERK2 protein, $50 \mu \mathrm{g}$ of total lysate was electrophoresed on a $10 \%$ polyacrylamide gel, blotted to nitrocellulose, and incubated with anti-ERK2. Immune complexes were detected by horseradish peroxidase second antibodies and then by enhanced chemiluminescence (Amersham). All experiments analyzing ERK2 phosphorylation and/or activation were repeated at least three times.

Measurement of $\left[\mathrm{Ca}^{2+}\right]_{\mathrm{i}}$. Nearly confluent rat-1 cells grown on glass coverslips were loaded with $10 \mathrm{mM}$ indo$1 / \mathrm{AM}$ at $37^{\circ} \mathrm{C}$. Measurements were performed in N-2-hydroxyethylpiperazine- $N^{\prime}$-2-ethanesulfonic acid (HEPES)buffered saline of the following composition: $\mathrm{KCl}, 5 \mathrm{mM}$; $\mathrm{NaCl}, 140 \mathrm{mM} ; \mathrm{CaCl}_{2}, 2 \mathrm{mM} ; \mathrm{MgCl}_{2}, 1 \mathrm{mM}$; HEPES, 10 $\mathrm{mM}$; and glucose, $10 \mathrm{mM}$. With a fluorescence spectrometer (Perkin-Elmer 3000), $\left[\mathrm{Ca}^{2+}\right]_{i}$ was determined, with an excitation wavelength of $355 \mathrm{~nm}$ (5-nm slit) and an emission wavelength of $405 \mathrm{~nm}$ (10-nm slit) according to standard procedures (14). PDGF-BB, stored in $1 \mathrm{M}$ acetic acid plus $0.01 \%$ bovine serum albumin, was Speed-Vac dried before use and resuspended in HEPES-buffered saline.

\section{RESULTS}

Activation of p21 ras and ERK2 by PDGF and EGF in rat-1 cells. Previously, we have investigated growth factor-induced p21 ras activation in NIH 3T3 fibroblasts. Both PDGF and EGF hardly induce p21 ${ }^{\text {ras }}$-GTP formation in these cells (7). Here we analyzed growth factor-induced $\mathrm{p} 21^{\text {ras }}$ activation in rat-1 cells. The rat-1 cell line used is highly responsive to growth factors with respect to the induction of $\left[{ }^{3} \mathrm{H}\right]$ thymidine incorporation and growth in soft agar $(8$, and data not shown), confirming the original characterization by Kaplan et al. (19). Rat-1 fibroblasts were stimulated with either PDGF and EGF for $5 \mathrm{~min}$, and GTP and GDP binding to p21 ras was determined (Fig. 1A). Both PDGF and EGF were found to stimulate p21 ras - GTP formation, although EGF gave rise to significantly higher relative levels of $\mathrm{p} 21^{\text {ras }}$-GTP compared with those induced by PDGF (basal, 17\% GTP; EGF, 55\% GTP; and PDGF, 25\% GTP $[n=4])$. EGF receptor numbers are somewhat lower than those of PDGF receptors on rat-1 cells, but they are comparable (PDGF receptor, $\sim 80,000$, and EGF receptor, $\sim 30,000$ [27a]), so in these cells, EGF appears to be a more efficient activator of p21 $1^{\text {ras }}$ than PDGF.

Next, we investigated the induction of ERK2 activity following either PDGF or EGF stimulation of rat-1 fibroblasts. Activation of ERK2 can be measured by an immune complex kinase assay, with myelin basic protein as a substrate, or alternatively, activation can be monitored by the appearance of a more slowly migrating form in gel electrophoresis caused by phosphorylation (27). Mutation of both Thr-183 and Tyr-185 results in a protein that can no longer be phosphorylated and lacks the mobility shift (37). However, formally it is not proven that the appearance of phosphorylated ERK2 is identical to the activation of ERK2 per se. Stimulation of rat-1 fibroblasts with EGF and PDGF induced a complete shift in ERK2 mobility, indicating full activation of ERK2 (Fig. 1B).

p21 ras involvement in PDGF and EGF signaling. Previously, we demonstrated the use of a vaccinia virus vector expressing the dominant negative $221^{\text {ras }}$ mutant $\mathrm{p}^{\text {ras }}{ }^{\text {rasn-17 }}$ (vV-p21 rasAsn-17) in dissecting growth factor pathways mediated by $\mathrm{p} 21^{\text {ras }}$ (12). These vectors, however, are not suitable for studying EGF signaling, since they express the gene encoding vaccinia virus growth factor (VGF). VGF can bind to the EGF receptor and stimulate EGF receptor activity (6). Therefore, we cloned p21 rasAsn-17 into a vaccinia virus vector lacking VGF gene expression (vv-152) (30). Expression of p21 rasAsn-17 was tested by infecting insulin receptor overexpressing NIH 3T3 cells (A14 cells) with various amounts of recombinant virus (Fig. 1C). Compared with the endogenous $221^{\text {ras }}, \mathrm{p}^{2} 1^{\text {ras Asn-17 }}$ was expressed at an approximately 10-fold-higher level ( $50 \mu \mathrm{l}$ [20 PFU] of recombinant virus) or at an equal level $(5 \mu \mathrm{l})$. Inhibition of insulin-induced ERK2 phosphorylation could already be observed at the lowest level of p21 rasAsn-17 expression and was complete when $\mathrm{p} 21^{\text {ras Asn }-19}$ was slightly overexpressed compared with endogenous $\mathrm{p} 21^{\text {ras }}$ (Fig. 1C). Therefore, in all further experiments using vv-152-p21 rasAsn-17, cells were infected with 50 $\mu 1$ of the virus stock. We also tested whether p21 rasAsn-17 expression blocks not only ERK2 phosphorylation but also activation, as measured by an immune complex kinase assay 
A

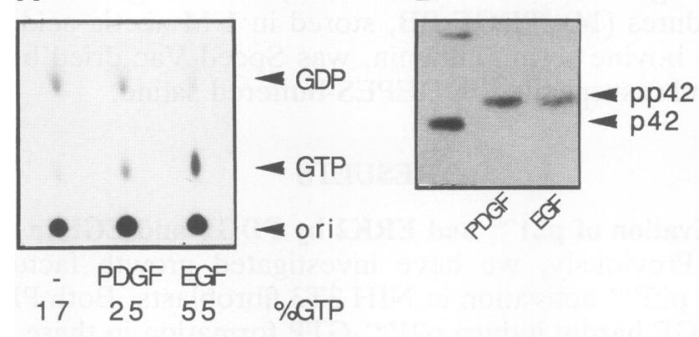

C

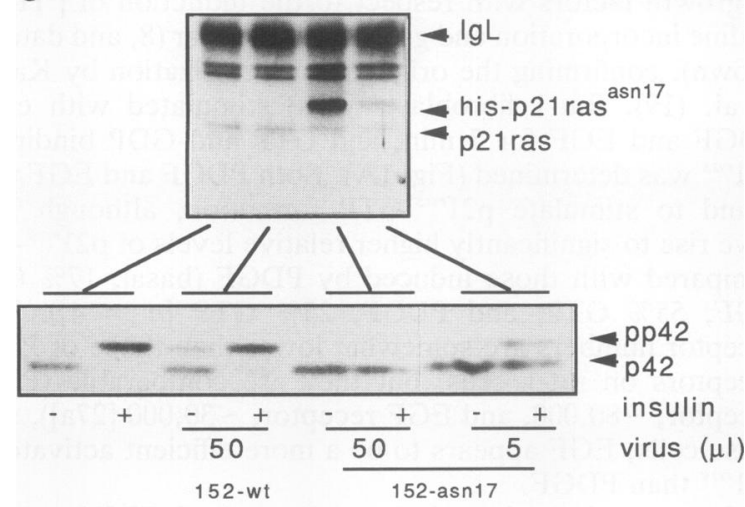

D

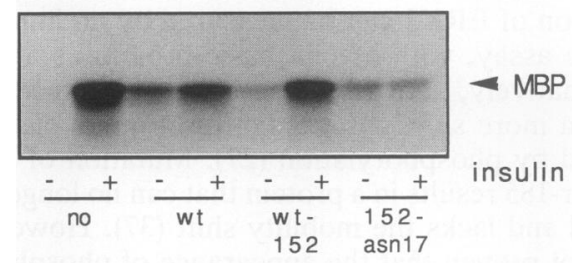

E

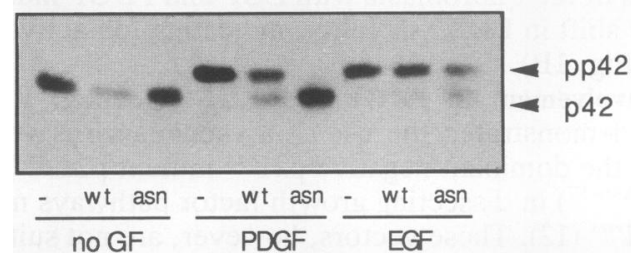

FIG. 1. PDGF-induced, but not EGF-induced, ERK2 phosphorylation in rat-1 cells is blocked by p21 ${ }^{\text {rasAsn-17. }}$. (A) Activation of p21 ras by PDGF and EGF in rat-1 cells. Serum-arrested rat-1 cells were treated with PDGF-BB homodimer $(50 \mathrm{ng} / \mathrm{ml})$ and EGF (20 $\mathrm{ng} / \mathrm{ml}$ ) for $5 \mathrm{~min}$. $\mathrm{p} 21^{\text {ras }}$ activation was measured by determining the nucleotide content of $\mathrm{p} 21^{\text {ras }}$. Shown is an autoradiogram of a TLC separation of guanine nucleotides. Indicated are the positions of the GTP and GDP standards, and under each lane, the average amount $(n=4)$ of $\mathrm{p}^{2} 1^{\text {ras }}$-GTP (as a percentage of total nucleotide bound to p21 ${ }^{\text {ras }}$ [GTP plus GDP]) is indicated. (B) Phosphorylation of ERK2 by PDGF and EGF in rat-1 cells. Serum-arrested rat-1 cells were treated with PDGF-BB homodimer $(50 \mathrm{ng} / \mathrm{ml})$ and EGF $(20 \mathrm{ng} / \mathrm{ml})$ for $5 \mathrm{~min}$, total protein lysates were prepared by scraping cells into sample buffer, and phosphorylation of ERK2 was determined by the occurrence of a mobility shift. The position of the unphosphorylated (inactive) ERK2 is indicated by p42, and the phosphorylated ERK2 is indicated by pp42. (C) Characterization of recombinant non-VGFproducing (vv-152) p21 rasAsn-17 expressing vaccinia virus. Construction of viruses has been described previously $(12,30)$. Cells overexpressing the insulin receptor (A14) were infected with various
(Fig. 1D). In agreement with our previous results (12), this construct was also found to inhibit insulin-induced ERK2 activation in A14 cells (Fig. 1D). In addition, the increase in basal ERK2 activity observed following infection with wildtype virus, presumably due to VGF expression, was reduced by using wild-type vv-152 (Fig. 1D, compare lanes wt - and wt + with lanes $152-$ and $152+$ ).

Next, we compared PDGF- and EGF-induced ERK2 phosphorylation in rat-1 cells following infection with $\mathrm{VV}$ 152-p21 rasAsn-17 (Fig. 1E). In contrast to PDGF, EGFinduced ERK2 phosphorylation was not inhibited by the expression of $\mathrm{p} 21^{\text {rasAsn-17. }}$

Activation of ERK2 by EGF occurs also through a p21 ras. independent pathway. As shown in Fig. 1A, the levels of p21 $1^{\text {ras }}$-GTP induced by EGF compared with those induced by PDGF are much higher. It would therefore be possible that the level of $\mathrm{p} 21^{\text {rasAsn-17 }}$ expression is sufficient to block p2 $1^{\text {ras }}$ activation completely following PDGF stimulation but not following EGF stimulation. A residual increase in $\mathrm{p} 21^{\text {ras }}$. GTP might then account for ERK2 phosphorylation. In NIH 3T3 cells overexpressing the insulin receptor (A14 cells), insulin and EGF induce similar levels of p21 ${ }^{\text {ras }}$-GTP as well as similar kinetics of ERK2 activation (Fig. 2A). Despite the fact that both insulin and EGF induce up to 60 to $70 \%$ p21 $1^{\text {ras }}$-GTP, only insulin-induced ERK2 phosphorylation is inhibited significantly by p21 ras Asn-17 expression (Fig. 2B).

We have previously shown that both insulin and EGF activate $\mathrm{p} 21^{\mathrm{ras}}$ by increasing nucleotide exchange (30). This mechanism of $\mathrm{p} 21^{\text {ras }}$ activation is blocked by $\mathrm{p} 21^{\text {ras } \mathrm{Asn}-17}$ expression $(5,30)$, and $21^{\text {rasAsn-17 }}$ has been shown to compete with endogenous $\mathrm{p} 21^{\text {ras }}$ for interaction with $\mathrm{mSos}$, a putative $21^{\text {ras }}$ nucleotide exchange factor, thus providing a rationale for the inhibition of $\mathrm{p} 21^{\text {ras }}$ activation (4). These results strongly suggest that $\mathrm{p} 21^{\text {ras Asn-17 }}$ will inhibit EGFinduced p $21^{\text {ras }}$ activation as efficiently as insulin-induced p $21^{\text {ras }}$ activation, since $\mathrm{p} 21^{\text {ras Asn-17 }}$ acts between activation of the exchange factor and p21 ${ }^{\text {ras }}$. However, the possibility that for some unknown reason EGF-induced $\mathrm{p} 21^{\text {ras }}$ activation activation is refractory to our approach of $\mathrm{p} 21^{\text {rasAsn-17 }}$ expression, by using vaccinia virus, still remains. For PC12

amounts of wild-type virus or recombinant virus and either left unstimulated or stimulated with insulin $\left(10^{-6} \mathrm{M}\right)$. Expression of p $21^{\text {rasAsn-17}}$ was determined by immunoprecipitation with the p21 ras specific monoclonal antibody Y13-238 and immunoblotting with Y13-259 to detect $\mathrm{p} 21^{\text {ras }}$ protein. Owing to the presence of six histidine residues at the $\mathrm{N}$ terminus, the $\mathrm{p} 21^{\text {ras Asn-15 }}$ protein runs at a slightly slower mobility than endogenous $\mathrm{p} 21^{\text {ras }}$. Of the lysates, 50 $\mu \mathrm{g}$ was used to determine phosphorylation of ERK2. The position of the unphosphorylated (inactive) ERK2 is indicated by p42, and the phosphorylated ERK2 is indicated by pp42. IgL, immunoglobulin light chain. (D) Activation of ERK2 is blocked by non-VGFproducing (Vv-152) p21 $1^{\text {ras Asn-17 }}$ expressing vaccinia virus. A14 cells were either left uninfected or infected with viruses $(50 \mu \mathrm{l})$ as indicated, prior to stimulation with insulin $\left(10^{-6} \mathrm{M}\right)$. ERK2 was immunoprecipitated, and ERK2 activity of immunoprecipitates was determined as described in Materials and Methods. MBP, myelin basic protein. (E) Phosphorylation of ERK2 in rat-1 cells by PDGF, but not EGF, is blocked by $\mathrm{p}^{2} 1^{\text {ras Asn-17 }}$ expression. Rat-1 cells either were left uninfected $(-)$ or were infected with control virus (wt) or with p21 rasAsn-17 virus (asn). Following infection cells were either left untreated (no GF) or treated with PDGF $(50 \mathrm{ng} / \mathrm{ml})$ or EGF (20 $\mathrm{ng} / \mathrm{ml}$ ) as indicated. The phosphorylation of ERK2 was determined by the occurrence of a mobility shift. The position of the unphosphorylated (inactive) ERK2 is indicated by p42, and the phosphorylated ERK 2 is indicated by pp42. 
A
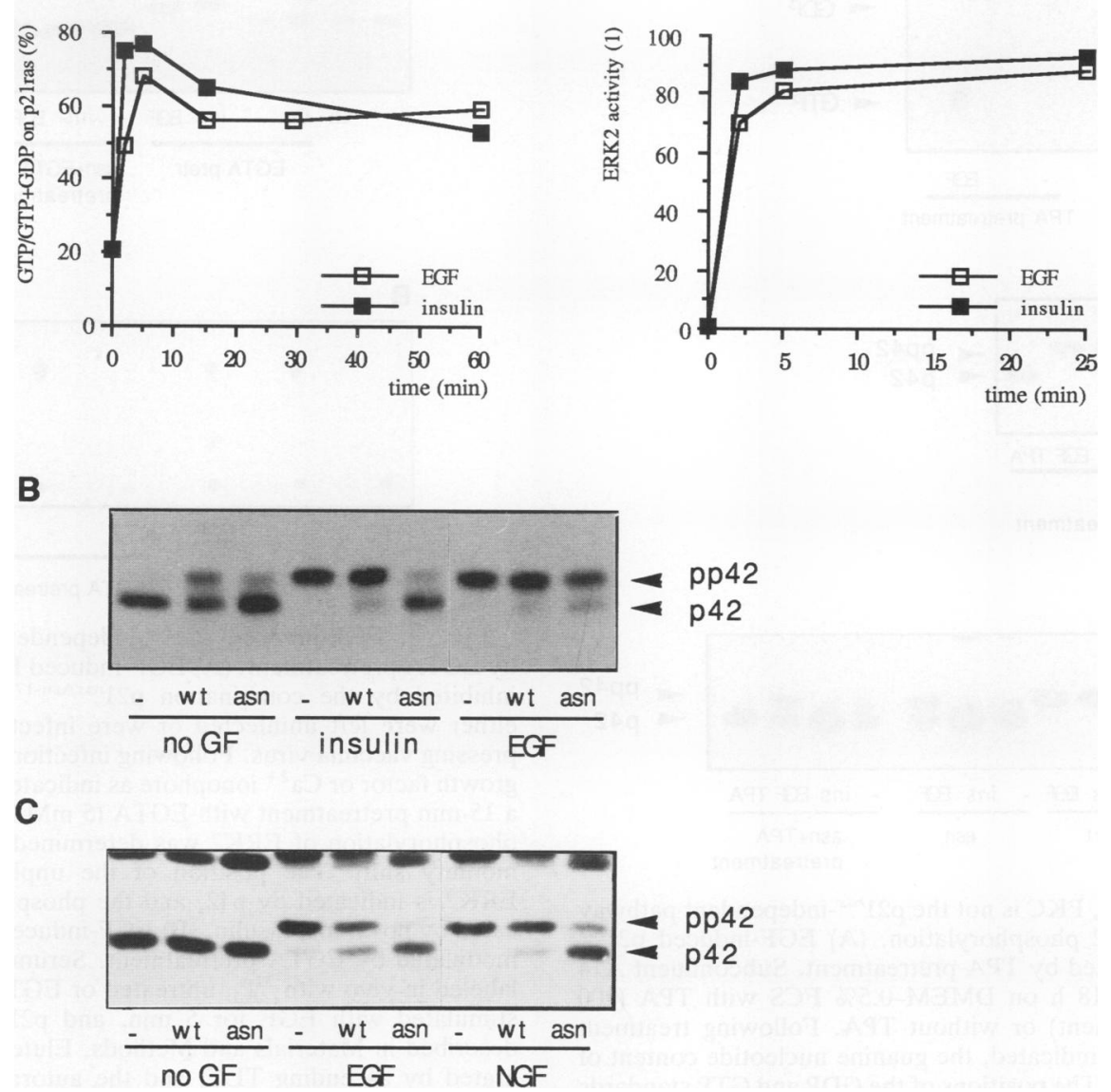

FIG. 2. Phosphorylation of ERK2 by EGF in A14 cells occurs through p21 ${ }^{\text {ras }}$-independent pathways. (A) Time course of EGF- and insulin-induced p21 ras activation and ERK2 activation in insulin receptor-overexpressing cells (A14 cells). A14 cells were serum arrested and treated for various times with either EGF $(20 \mathrm{ng} / \mathrm{ml})$ or insulin $\left(10^{-6} \mathrm{M}\right)$. Activation of p21 ras and ERK2 was measured as described in the legend to Fig. 1A and D, respectively. The percentage of GTP is expressed as relative to the total amount of labeled nucleotide (GTP + GDP). The activation of ERK2 is expressed as an apparent enzyme activity ( $1 \mathrm{U}=1$ pmol of $\mathrm{PO}_{4}$ per min per $100 \mu \mathrm{g}$ of total protein). (B) Phosphorylation of ERK2 in A14 cells by insulin, but not EGF, is blocked by p21 rasAsn-17 expression. A14 cells either were left uninfected $(-)$ or were infected with control virus (wt) or with p21 rasAsn-17 virus (asn). Following infection, cells either were left untreated (no GF) or were treated with insulin $\left(10^{-6} \mathrm{M}\right)$ or EGF $(20 \mathrm{ng} / \mathrm{ml})$ as indicated. The phosphorylation of ERK2 was determined by the occurrence of a mobility shift. The position of the unphosphorylated (inactive) ERK2 is indicated by p42, and the phosphorylated ERK2 is indicated by pp42. (C) Effects of p21 rasAsn-17 expression on EGF- and NGF-induced ERK2 phosphorylation in PC12 cells. PC12 cells either were left uninfected $(-)$ or were infected with control virus (wt) or with p21 rasAsn-17 virus (asn). Following infection, cells were either left untreated (no GF) or treated with EGF $(20 \mathrm{ng} / \mathrm{ml})$ or NGF $(20 \mathrm{ng} / \mathrm{ml})$ as indicated. The phosphorylation of ERK2 was determined by the occurrence of a mobility shift. The position of the unphosphorylated (inactive) ERK2 is indicated by p42, and the phosphorylated ERK2 is indicated by pp42.

cells, it has been shown that induction of $\mathrm{p} 21^{\text {ras Asn-17 }}$ expression inhibits EGF-induced ERK2 activity $(42,45)$. Therefore, we tested the ability of $\mathrm{vv}-152-\mathrm{p} 21^{\text {ras Asn-17 }}$ to inhibit EGF signaling in PC12 cells. As shown in Fig. 2C, infection of PC12 cells with vv-152-p21 rasAsn-17 efficiently inhibits EGF-induced ERK2 phosphorylation. This demonstrates that the observed lack of inhibition of EGF-induced ERK2 phosphorylation in rat-1 and A14 cells is not inherent to the use of the VV-152-p21 rasAsn-17 construct to express p21 rasAsn17.

In conclusion, these results suggest that in rat-1 and A14 cells, ERK2 phosphorylation by EGF occurs through the activation of $221^{\text {ras }}$ but that EGF activates a pathway that is fully capable of stimulating ERK2 phosphorylation in the absence of $\mathrm{p} 21^{\text {ras }}$ activation.
TPA-sensitive PKC is not involved in EGF-induced p21 ${ }^{\text {ras }}$. independent ERK2 phosphorylation in A14 cells. If p21 ras activation is not the only determinant in EGF signaling towards ERK2, what, then, can be the other(s)? Activation of PKC by short-term treatment with 12-O-tetradecanoylphorbol-13-acetate (TPA) induces ERK2 activation (10) (Fig. 3B, lane 4). However, identical treatment does not result in a significant activation of p21 ras (29). In addition, TPA-induced ERK2 activation is also not inhibited by p21 rasAsn-17 expression (12) (see Fig. 6C). These results suggest the possibility of growth factor-induced activation of TPA-sensitive PKC as a pathway of p $21^{\text {ras }}$-independent activation of ERK2. To study a role for this pathway in the induction of ERK2 phosphorylation by EGF, A14 cells were depleted of TPA-sensitive PKC by prolonged treatment with 


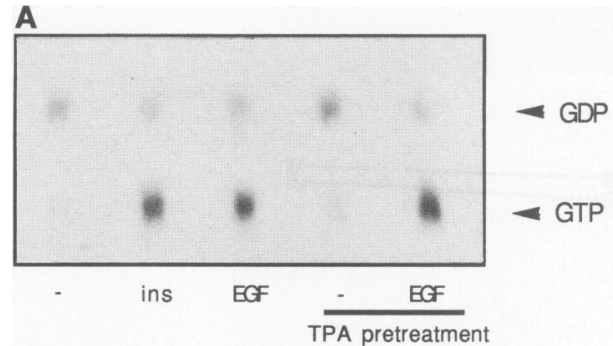

B

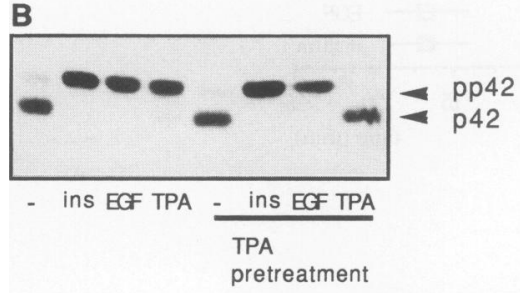

C

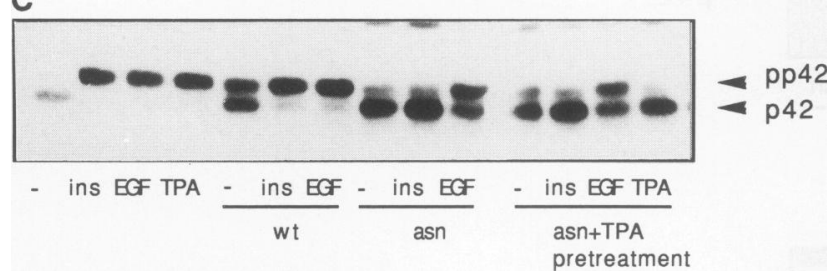

FIG. 3. In $\mathrm{A} 14$ cells, $\mathrm{PKC}$ is not the $\mathrm{p} 21^{\text {ras }}$-independent pathway in EGF-induced ERK2 phosphorylation. (A) EGF-induced p21 ras activation is not inhibited by TPA pretreatment. Subconfluent A14 cells were grown for $18 \mathrm{~h}$ on DMEM-0.5\% FCS with TPA (200 $\mathrm{ng} / \mathrm{ml}$ ) (TPA pretreatment) or without TPA. Following treatment with growth factors as indicated, the guanine nucleotide content of $\mathrm{p} 21^{\text {ras }}$ was determined. The positions of the GDP and GTP standards are indicated. (B) EGF-induced ERK2 phosphorylation is not inhibited by TPA pretreatment. A14 cells were treated and stimulated as described for panel A; TPA stimulation was with $100 \mathrm{ng} / \mathrm{ml}$. ERK2 phosphorylation was determined by the occurrence of a mobility shift. The position of the unphosphorylated (inactive) ERK2 is indicated by $\mathrm{p} 42$, and the phosphorylated ERK2 is indicated by pp42. (C) EGF induces ERK2 phosphorylation by a p21 ras -independent and PKC-independent pathway. A14 cells either were left uninfected or were infected with control virus (wt) or with p21 $1^{\text {ras Asn-17 }}$ virus (asn) either alone or in combination with TPA (100 $\mathrm{ng} / \mathrm{ml}$ ) pretreatment (asn+TPA pretreatment). Following infection, cells either were left untreated ( - ) or were stimulated with EGF (20 $\mathrm{ng} / \mathrm{ml})$, insulin (ins; $\left.10^{-6} \mathrm{M}\right)$, or TPA $(100 \mathrm{ng} / \mathrm{ml})$ as indicated. The phosphorylation of ERK2 was determined by the occurrence of a mobility shift. The position of the unphosphorylated (inactive) ERK2 is indicated by p42, and the phosphorylated ERK2 is indicated by pp42.

TPA. This resulted in the loss of immunodetectable PKC, TPA-inducible myristylated arginine-rich $C$ kinase substrate (MARCKS) phosphorylation, and TPA-induced ERK2 activation (Fig. 3B) (data not shown) (29). Under these conditions, both EGF-induced p21 ras activation (Fig. 3A) and EGF-induced ERK2 phosphorylation (Fig. 3B) are not affected. In the case of EGF it can be proposed that neither p $21^{\text {ras }}$ nor PKC signaling is essential but that both are sufficient. Therefore, we analyzed the possibility that both pathways are employed in EGF signaling towards ERK2 phosphorylation. To this end, EGF-induced ERK2 phosphorylation was analyzed in PKC depleted, vv-152-p21 ras Asn-17.
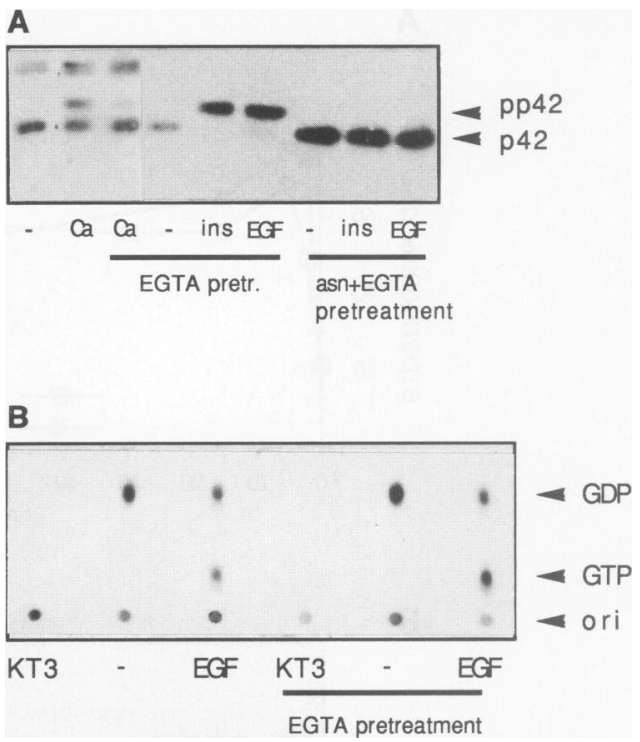

FIG. 4. EGF-induced $221^{\text {ras }}$-independent signaling is inhibited by EGTA pretreatment. (A) EGF-induced ERK2 phosphorylation is inhibited by the combination $\mathrm{p} 21^{\text {rasAsn-17}}$ and EGTA. A14 cells either were left uninfected or were infected with p21 ${ }^{\text {rasAsn-17 }}$ expressing vaccinia virus. Following infection, cells were treated with growth factor or $\mathrm{Ca}^{2+}$ ionophore as indicated, either with or without a 15 -min pretreatment with EGTA ( $5 \mathrm{mM}$ final concentration). The phosphorylation of ERK2 was determined by the occurrence of a mobility shift. The position of the unphosphorylated (inactive) ERK2 is indicated by p42, and the phosphorylated ERK2 is indicated by pp42. ins, insulin. (B) EGF-induced p21 $1^{\text {ras }}$ activation is not modulated by EGTA pretreatment. Serum-starved A14 cells were labeled in vivo with ${ }^{32} \mathrm{P}_{\mathrm{i}}$, untreated or EGTA pretreated cells were stimulated with EGF for $5 \mathrm{~min}$, and p21 ras was precipitated as described in Materials and Methods. Eluted nucleotides were separated by ascending TLC, and the autoradiogram of the TLC is shown.

infected A14 cells (Fig. 3C). As shown in Fig. 3C, this did not result in complete inhibition of EGF-induced ERK2 phosphorylation. For rat-1 cells, essentially identical results were obtained (not shown). Thus, it appears that activation of a TPA-sensitive PKC is not the p2 $1^{\text {ras }}$-independent pathway in EGF signaling towards ERK2 activation in rat-1 and A14 cells.

Involvement of $\mathrm{Ca}^{2+}$-dependent pathways in EGF-induced ERK2 activation. The role of $\mathrm{Ca}^{2+}$ in EGF signaling has been well documented (reference 36 and references therein). Therefore, in search of other signaling pathways involved in EGF-induced ERK2 phosphorylation, we analyzed the involvement of $\mathrm{Ca}^{2+}$-dependent pathways. First, we tested whether $\mathrm{Ca}^{2+}$ by itself could induce ERK2 phosphorylation in A14 cells. The $\mathrm{Ca}^{2+}$ ionophore ionomycin rapidly induced ERK2 phosphorylation (Fig. 4A). This induction was dependent on $\mathrm{Ca}^{2+}$, since pretreatment of cells for $5 \mathrm{~min}$ with EGTA to sequester extracellular $\mathrm{Ca}^{2+}$ did inhibit ionomycininduced ERK2 phosphorylation. This also indicates that the EGTA concentration used is sufficient to inhibit signaling induced by a large increase in intracellular $\mathrm{Ca}^{2+}$, as in the case of ionomycin. In contrast, EGTA pretreatment did not significantly affect EGF-, insulin (Fig. 4A)- or PDGF (not shown)-induced ERK2 phosphorylation. Again, we tested whether a combination of p21 rasAsn-17 expression and EGTA pretreatment could block EGF-induced ERK2 phosphoryla- 

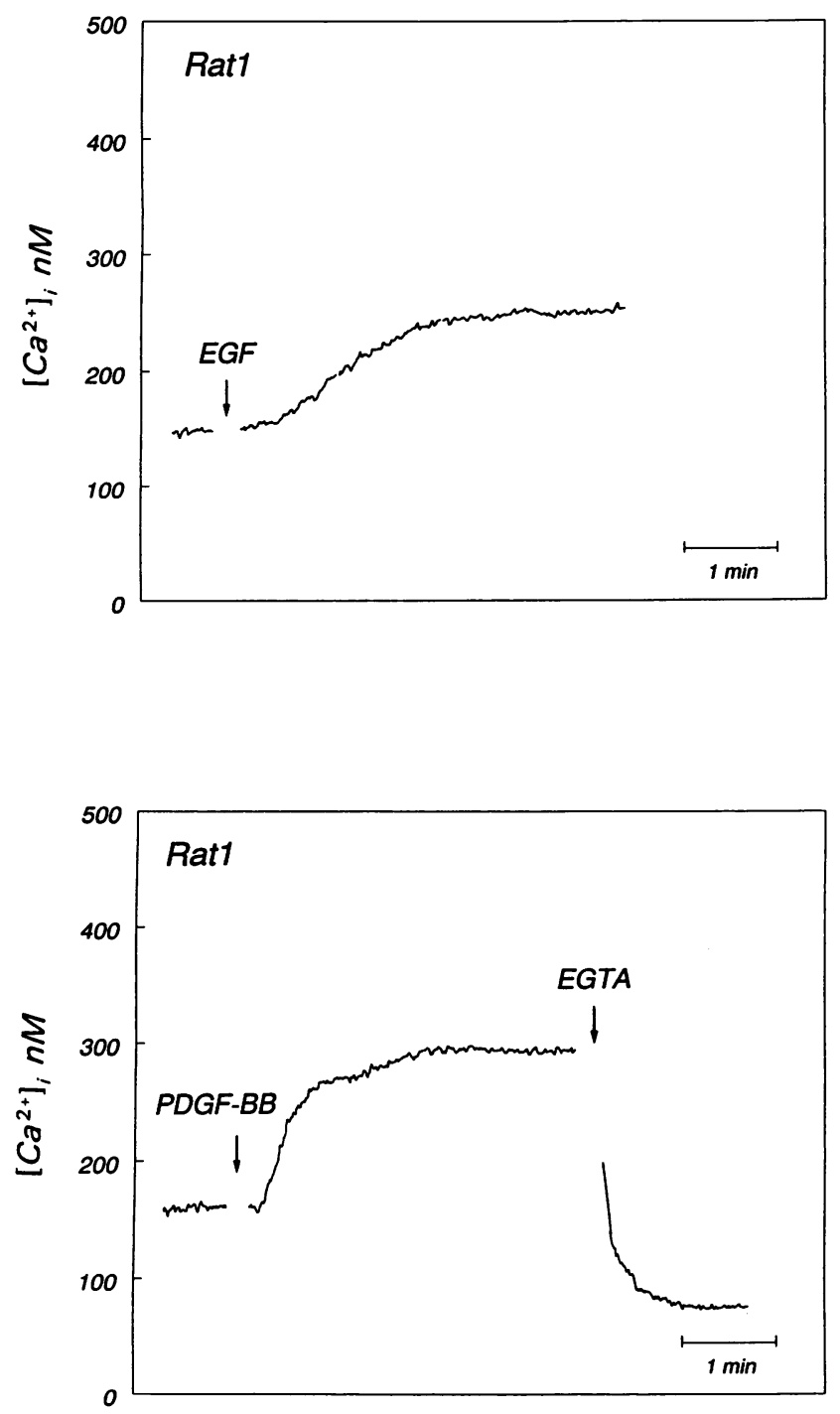

FIG. 5. PDGF- and EGF-induced $\mathrm{Ca}^{2+}$ fluxes. Serum arrested rat- 1 cells were loaded with indo-1/AM as described in Materials and Methods. Following treatment with growth factor, fluorescence was monitored in time. A trace is shown from a representative experiment following EGF and PDGF treatment.

tion (Fig. 4A). Interestingly, the phosphorylation of ERK2 by EGF was now completely blocked. EGF-induced phosphorylation of ERK2 in EGTA-pretreated, p21 rasAsn-17-infected rat-1 cells was also completely blocked (not shown). As shown in Fig. 4B, EGTA pretreatment did not significantly alter EGF-induced p21 ras activation. This suggests that EGTA pretreatment defines a pathway separate from that of p21 ras. We conclude from these results that in A14 and rat- 1 cells, both the $\mathrm{p}^{\text {ras }}$ and the $\mathrm{Ca}^{2+}$-mediated pathways for EGF signaling towards ERK2 appear sufficient, but neither one is essential.

PDGF- and EGF-induced $\mathrm{Ca}^{2+}$ response. If the second pathway towards ERK2 phosphorylation employed by EGF is induced by $\mathrm{Ca}^{2+}$ entry, then it is to be expected that insulin and PDGF would differ from EGF in this respect. To test whether there is a difference between PDGF and EGF signaling with respect to their ability to induce $\mathrm{Ca}^{2+}$ fluxes, rat-1 cells were loaded with indo-1/AM and stimulated with
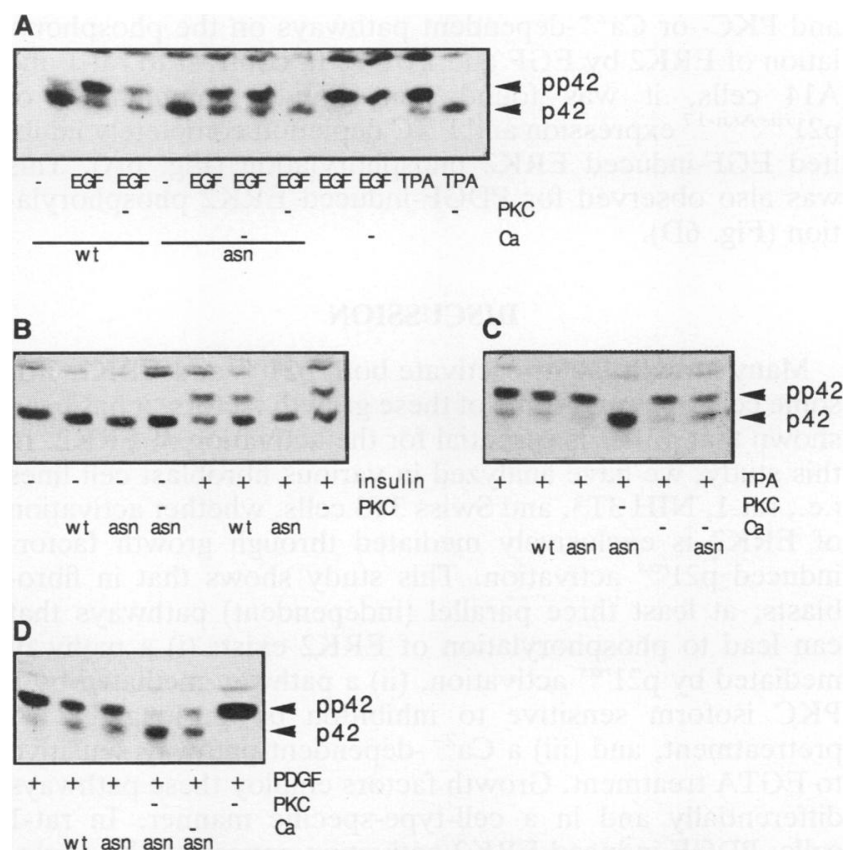

FIG. 6. p21 ras -dependent and -independent signaling in Swiss $3 T 3$ cells. Serum-arrested Swiss 3T3 cells either were left uninfected or were infected with wild-type vaccinia virus (wt) or p21 rasAsn-17 expressing virus (asn). In some cases, uninfected or infected cells were also pretreated with TPA $(300 \mathrm{ng} / \mathrm{ml}$ for $16 \mathrm{~h})$ to downmodulate PKC expression (indicated as PKC-) or pretreated with EGTA (indicated by $\mathrm{Ca}-$ ) before growth factor stimulation. Shown are representative examples of the analysis of induction of ERK2 phosphorylation by EGF (A), insulin (B), TPA (C), and PDGF (D). As before, the phosphorylation of ERK2 was determined by the occurrence of a mobility shift. The position of the unphosphorylated (inactive) ERK2 is indicated by p42, and the phosphorylated ERK2 is indicated by pp42.

PDGF or EGF, and $\mathrm{Ca}^{2+}$ traces were recorded. As shown in Fig. 5, it is clear that the $\mathrm{Ca}^{2+}$ transients induced by EGF and PDGF are very similar. This indicates that $\mathrm{Ca}^{2+}$ mobilization by itself is not the difference between EGF and PDGF signaling in rat-1 cells. Apparently, EGTA pretreatment defines a pathway towards ERK2 phosphorylation that is not $\mathrm{Ca}^{2+}$ induced but is $\mathrm{Ca}^{2+}$ dependent, yet specifically induced by EGF and not by PDGF.

Growth factor-induced ERK2 activation in Swiss 3T3 cells. Next, we addressed the question whether in other fibroblast cell lines EGF employs a similar redundant mechanism of ERK2 phosphorylation as in rat-1 and A14 cells. We chose to study Swiss 3T3 cells, since in these cells a role for TPA-sensitive PKC has been described in the activation of ERK2 by oncogenic p21 ras (27). Also, in Swiss 3T3 cells, expression of p21 rasAsn-17 did not inhibit EGF- or TPAinduced ERK2 phosphorylation (Fig. 6A and C). However, insulin-induced phosphorylation of ERK2 was completely blocked by $\mathrm{p} 21^{\text {ras Asn-17 }}$ expression, suggesting that insulin again activates only the p21 $1^{\text {ras }}$-mediated branch of ERK2 phosphorylation (Fig. 6B). As for the other fibroblast cell lines, TPA induced ERK2 phosphorylation by a p21 ras. independent pathway fully blocked by prolonged TPA pretreatment (Fig. 6C). Surprisingly, in contrast to rat-1 cells, PDGF-induced ERK2 phosphorylation was not inhibited by p21 rasAsn-17 expression (Fig. 6D). As described above for the other cell lines, we tested the effect of inhibiting both p21 ras 
and PKC- or $\mathrm{Ca}^{2+}$-dependent pathways on the phosphorylation of ERK2 by EGF and PDGF. In contrast to rat-1 and A14 cells, it was found that now a combination of p21 rasAsn-17 expression and PKC depletion completely inhibited EGF-induced ERK2 phosphorylation (Fig. 6A). This was also observed for PDGF-induced ERK2 phosphorylation (Fig. 6D).

\section{DISCUSSION}

Many growth factors activate both $\mathrm{p} 21^{\text {ras }}$ and ERK2. For some cell types and some of these growth factors, it has been shown that p21 ras is essential for the activation of ERK2. In this study, we have analyzed in various fibroblast cell lines i.e., rat-1, NIH 3T3, and Swiss 3T3 cells, whether activation of ERK2 is exclusively mediated through growth factorinduced $\mathrm{p} 21^{\text {ras }}$ activation. This study shows that in fibroblasts, at least three parallel (independent) pathways that can lead to phosphorylation of ERK2 exist: (i) a pathway mediated by $\mathrm{p} 21^{\text {ras }}$ activation, (ii) a pathway mediated by a PKC isoform sensitive to inhibition by prolonged TPA pretreatment, and (iii) a $\mathrm{Ca}^{2+}$-dependent pathway sensitive to EGTA treatment. Growth factors employ these pathways differentially and in a cell-type-specific manner. In rat-1 cells, PDGF-induced ERK2 activation appears to be exclusively mediated by $\mathrm{p} 21^{\text {ras }}$, since expression of $\mathrm{p} 21^{\text {ras } \mathrm{Asn}-17}$ completely inhibits ERK2 activation, and PKC depletion or EGTA treatment has no effect. In contrast, ERK2 activation by TPA is not mediated by $\mathrm{p} 21^{\text {ras }}$ and requires a TPAsensitive PKC. The activation of ERK2 by EGF appears to be mediated by two pathways acting simultaneously. The first pathway involves p $21^{\text {ras }}$, whereas the second is dependent on extracellular $\mathrm{Ca}^{2+}$. This conclusion is based upon the following observations. First, EGF induces p21 ras activation and a transient increase in $\mathrm{Ca}^{2+}$. Second, blocking only $\mathrm{Ca}^{2+}$ increase or p21 ${ }^{\text {ras }}$ activation does not inhibit ERK2 phosphorylation significantly. Third, this failure to fully block EGF-induced ERK2 phosphorylation was not due to incomplete inhibition of $\mathrm{p} 21^{\text {ras }}$ activation by

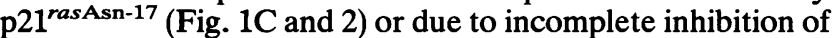
the $\mathrm{Ca}^{2+}$ increase (Fig. 4A). Fourth, only combined inhibition of $\mathrm{Ca}^{2+}$ influx and $21^{\text {ras }}$ activation resulted in full inhibition of ERK2 phosphorylation.

In Swiss 3T3 cells, growth factor induction of ERK2 activity occurs along similar pathways, yet compared with rat-1 and A14 cells, the ability of growth factors to activate these pathways is different. In this cell line, PDGF and EGF activate both the p21 ras - and the (TPA-sensitive) PKCmediated pathways. However, other stimuli activate only either one pathway, e.g., insulin activates the $\mathrm{p} 21^{\text {ras }}$-mediated pathway and TPA activates the PKC-mediated pathway. Other studies analyzing the effects of PKC inhibition have already suggested that in Swiss $3 T 3$ cells and derivatives (3T3-TNR9), activation of ERK2 occurs through PKCdependent and -independent pathways $(20,25)$. From our experiments it is apparent that the $\mathrm{p} 21^{\text {ras }}$-mediated pathway is this PKC-independent pathway. In addition, this corroborates the notion that, also in the Swiss 3T3 cells, lack of inhibition by $\mathrm{p}^{21^{\text {ras Asn-17 }}}$ is not due to insufficient expression of $21^{\text {ras Asn-17 }}$

Several observations argue that the above-mentioned pathways are indeed independent pathways. PKC-mediated activation of ERK2 in fibroblasts is different from $\mathrm{p} 21^{\text {ras }}$ mediated ERK2 activation, since stimulation of fibroblasts with TPA does not result in p21 ${ }^{\text {ras }}$ activation. TPA-induced ERK2 activation is not blocked by p21 rasAsn-17 expression, and TPA pretreatment does not (rat-1 and A14) or only modestly (Swiss 3T3) attenuates tyrosine kinase receptorinduced ERK2 activation. This conclusion appears to contrast with some other reports studying the relationship of $\mathrm{PKC}$ and $\mathrm{p} 21^{\text {ras }}$ in which PKC is positioned either upstream or downstream of $\mathrm{p} 21^{\text {ras }}$. It should be noted, however, that some of these studies make use of the properties of oncogenic $\mathrm{p} 21^{\text {ras }}$, which is not necessarily identical to growth factor-stimulated increase in p21 ${ }^{\text {ras }}$-GTP (for a discussion, see reference 12). Furthermore, in these studies p2 $1^{\text {rasAsn-17 }}$ is introduced by scrape loading or transient transfection, and the expression levels of p21 rasAsn-17 we achieve may be lower than those obtained after transient transfection or scrape loading of $\mathrm{p} 21^{\text {ras Asn-17 }}$ protein. In $\mathrm{PC} 12$ cells, a differential effect of $\mathrm{p} 21^{\text {ras Asn-17 }}$ expression has already been noted. Low levels of p21 rasAsn-17 block the NGF-induced differentiation response but not NGF-induced expression of early response genes (c-fos and c-jun); high levels of p21 rasAsn-17 also block NGF-induced early response gene expression (41). Whether high levels of p21 ras Asn-17 expression inhibit only p $21^{\text {ras }}$-mediated events or also result in aspecific inhibition of receptor signalling remains to be established. Irrespective of this, the level of p21 rasAsn-17 expression we obtain (Fig. 1C) is sufficient to inhibit the induction of high levels of p21 ${ }^{\text {ras }}$-GTP by insulin in A14 cells (60 to $70 \%$ GTP) to such an extent that insulin-induced ERK2 phosphorylation and activation is inhibited not only in these cells but also in Swiss 3T3 cells (Fig. 1C, 1D, 2B, and 6B) (30). Finally, recent results show that certain PKC isozymes can directly activate the Raf- 1 kinase and thereby ERK2 $(21,39)$. This would indicate that the PKC-mediated pathway and the p $21^{\text {ras }}$-mediated pathway converge at the level of Raf-1 kinase activation.

The pathway defined by EGTA pretreatment appears to be different from the $\mathrm{p} 21^{\text {ras }}$-mediated pathway. Pretreating cells with EGTA does not affect EGF-induced p21 ${ }^{\text {ras }}$ activation, suggesting that at least EGF-induced $\mathrm{Ca}^{2+}$ mobilization does not play an essential role in EGF-induced $\mathrm{p} 21^{\text {ras }}$ activation. Still, $\mathrm{Ca}^{2+}$-dependent signaling may be involved in modulating p $21^{\text {ras }}$-GTP levels. For example, in situ activation of p $21^{\text {ras }}$ in permeabilized $\mathrm{T}$ cells is slightly lowered in $\mathrm{Ca}^{2+}$. free medium (18). Also, we observed a small increase in p21 ${ }^{\text {ras }}$-GTP levels, although not reproducibly, after treatment with $\mathrm{Ca}^{2+}$ ionophore. Therefore, we cannot fully exclude the possibility that the $\mathrm{Ca}^{2+}$-dependent signal converges towards the ERK2 pathway at the level of p21 ras activation. If so, this would indicate that the mechanism by which the $\mathrm{Ca}^{2+}$-dependent signal contributes to $\mathrm{p}^{2} 1^{\text {ras }}$ activation is independent of the recently proposed mSos-mediated pathway (reviewed in reference 28 ), since our experiments with insulin suggest that p21 rasAsn-17 expression completely blocks this pathway. Inactivation of $21^{\text {ras }}$ GTPase-activating proteins by the $\mathrm{Ca}^{2+}$-dependent pathway may be such a mSos-independent $\mathrm{p} 21^{\text {ras }}$-activating pathway.

At present the nature of the signal that is blocked by EGTA pretreatment is unknown. It is important to stress that apparently a $\mathrm{Ca}^{2+}$-dependent signal and not a $\mathrm{Ca}^{2+}$. induced signal is involved. The experiments using the $\mathrm{Ca}^{2+}$ ionophore ionomycin show that $\mathrm{Ca}^{2+}$ influx by itself can induce ERK2 phosphorylation, as was also reported by Chao et al. for human foreskin cells (9). However, the increase in intracellular $\mathrm{Ca}^{2+}$ after ionophore treatment is more than 10-fold higher than obtained with any natural agonist that increases intracellular $\mathrm{Ca}^{2+}$. For instance, treatment of rat-1 cells with endothelin, inducing a strong $\mathrm{Ca}^{2+}$ response, results in only a very small increase of ERK2 

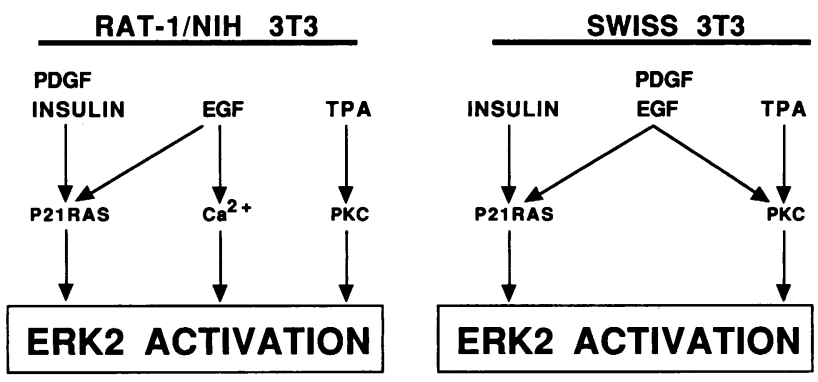

FIG. 7. ERK2 signaling pathways in fibroblasts. Different pathways leading to operational ERK2 phosphorylation and activation in rat-1, NIH 3T3, and Swiss 3T3 fibroblasts as identified in this study. p21 ras is the pathway inhibited by $21^{\text {ras Asn-17 }}$ expression, $\mathrm{Ca}^{2+}$ is the $\mathrm{Ca}^{2+}$-dependent pathway defined by EGTA pretreatment, and $\mathrm{PKC}$ is the pathway involving those PKC isozymes that can be inhibited by a prolonged pretreatment with TPA. For a detailed discussion, see the text.

activity. In addition, when analyzing a dose response for endothelin, the induction of ERK 2 activity does not appear to correlate with the ability of endothelin to stimulate an increase in $\mathrm{Ca}^{2+}$ (32) (data not shown). Finally, we compared EGF and PDGF with respect to the ability to induce an increase in intracellular $\mathrm{Ca}^{2+}$, and no differences were observed (Fig. 5). Yet EGF, and not PDGF, induced a redundant, $\mathrm{Ca}^{2+}$-dependent, signaling pathway towards ERK2. Thus, it appears that EGF can induce an EGFspecific, $\mathrm{Ca}^{2+}$-dependent enzyme activity involved in regulating ERK2 activity.

Since in Swiss 3 T3 cells a PKC isozyme is involved, it would be possible that in rat-1 and A14 cells an EGTAsensitive, but not TPA-sensitive, PKC isozyme is involved in EGF signaling. Molecular cloning analysis of PKC has revealed a family of multiple isoforms (for a review, see reference 34). A marked difference between these isoforms is their sensitivity to $\mathrm{Ca}^{2+}$. CPKC $\alpha,-\beta I,-\beta I I$, and $-\gamma$ are dependent on $\mathrm{Ca}^{2+}$ for their activity, whereas $\mathrm{NPKC} \varepsilon,-\delta,-\zeta$, and $-\eta / L$ are not. The EGTA pathway in EGF signaling towards ERK2 as defined in this study could thus involve the isoforms $\mathrm{cPKC} \alpha,-\beta \mathrm{I},-\beta \mathrm{II}$, and $-\gamma$. The ability to downregulate certain PKC isoforms by prolonged treatment with TPA differs between cell lines. Immunoblotting with monoclonal antibody MC5 (Amersham), detecting cPKC $\alpha$, showed complete loss of immunodetectable PKC in A14 cells (data not shown). This leaves the possibility that cPKC $\beta I$, $-\beta$ II, or $-\gamma$ is involved in $\mathrm{Ca}^{2+}$-dependent ERK2 activation. However, EGTA pretreatment by itself or in combination with $221^{\text {ras Asn-17 }}$ expression did not block TPAinduced ERK2 phosphorylation (Fig. 6C) (data not shown). Furthermore, in human foreskin fibroblasts, $\mathrm{Ca}^{2+}$ does appear to activate ERK2 without activating PKC (9). Finally, Buday and Downward, using our clone of rat-1 cells, have obtained no evidence of PKC activation following EGF treatment (5). From these data, we conclude that in these cells activation of $\mathrm{PKC}$ is not involved in EGF-induced phosphorylation of ERK2 mediated by $21^{\text {ras }}$ and also that the pathway which is blocked by EGTA is unlikely to involve PKC.

The results described in this report suggest a model for cell-type-specific signaling towards ERK2 that is depicted in Fig. 7. In fibroblasts we can discriminate three different pathways that can coexist within one cell type: a p21 ${ }^{\text {ras }}$. mediated pathway inhibited by p21 rasAsn-17 expression, a
PKC-mediated pathway inhibited by TPA pretreatment, and a $\mathrm{Ca}^{2+}$-dependent pathway inhibited by EGTA pretreatment. Depending on the cell type, growth factors may connect to one or more of these pathways. The cellular context, i.e., lack of mediators or presence of inhibitors, will determine which of these connections is made. It is clear that our results do not provide a quantitative measurement of the relative percentages at which these different pathways contribute to ERK2 activation; rather, they provide a qualitative measurement of the type of pathways involved in ERK2 activation. Also, at present we do not know whether these pathways converge at the level of ERK2 activation or at some level preceding ERK2 activation. For the PKC-mediated pathway, it is clear that it may converge at the level of Raf-1 kinase activation $(21,39)$. Whether the $\mathrm{Ca}^{2+}$-dependent signal also converges at the Raf-1 kinase level is currently under investigation. Our studies thus far suggest that for all genuine growth factors (not TPA), the p21 $1^{\text {ras }}$. mediated pathway is a common factor. In this respect it is noteworthy that in all insulin-responsive cells tested thus far, insulin will activate ERK2 only by the p $21^{\text {ras }}$-dependent pathway. This is in agreement with earlier findings $(2,33)$ that led to the suggestion that growth factor signaling could be divided in an insulin-like branch and a growth factorspecific branch.

\section{ACKNOWLEDGMENTS}

We thank Paul Coffer and all members of the laboratory for critically reading the manuscript and for useful comments. We thank Johan Van Lint (University of Leuven) for generously providing Swiss 3T3 cells and Chris Marshall (Chester Beatty Laboratories, London, England) for bacterially produced ERK2.

The research described was financially supported in part by the Dutch Cancer Society.

\section{REFERENCES}

1. Anderson, N. G., J. L. Maller, N. K. Tonks, and T. W. Sturgill. 1990. Requirement for integration of signals from two distinct phosphorylation pathways for the activation of MAP kinase. Nature (London) 343:348-350.

2. Blackshear, P. J., L. A. Witters, P. R. Girard, J. F. Kuo, and S. N. Quamo. 1985. Growth factor-stimulated protein phosphorylation in 3T3-L1 cells. Evidence for protein kinase C-dependent and -independent pathways. J. Biol. Chem. 260:13304 13315.

3. Boulton, T. G., S. H. Nye, D. J. Robbins, N. Y. Ip, E. Radziejewska, S. D. Morgenbesser, R. A. DePinho, N. Panayotatos, M. H. Cobb, and G. D. Yancopoulos. 1991. ERKs: a family of protein-serine/threonine kinases that are activated and tyrosine phosphorylated in response to insulin and NGF. Cell 65:663-675.

4. Buday, L., and J. Downward. 1993. Epidermal growth factor regulates $\mathrm{p} 21^{\text {ras }}$ through the formation of a complex of receptor, Grb2 adaptor protein, and SOS nucleotide exchange factor. Cell 73:611-620.

5. Buday, L., and J. Downward. 1993. Epidermal growth factor regulates the exchange rate of guanine nucleotides on $\mathrm{p} 21^{\text {ras }}$ in fibroblasts. Mol. Cell. Biol. 13:1903-1910.

6. Buller, R. M. L., S. Chakrabarti, B. Moss, and T. Frederickson. 1988. Cell proliferative response to vaccinia virus is mediated by VGF. Virology 164:182-192.

7. Burgering, B. M. T., R. H. Medema, J. A. Maassen, M. L. Van de Wetering, A. J. Van der Eb, F. McCormick, and J. L. Bos. 1991. Insulin stimulation of gene expression mediated by p21ras activation. EMBO J. 10:1103-1109.

8. Burgering, B. M. T., A. J. Snijders, J. A. Maassen, A. J. van der Eb, and J. L. Bos. 1989. Possible involvement of normal p21 $\mathrm{H}-$ ras in the insulin/insulinlike growth factor 1 signal transduction pathway. Mol. Cell. Biol. 9:4312-4322. 
9. Chao, T.-S. O., K. L. Byron, K.-M. Lee, M. Villereal, and M. R. Rosner. 1992. Activation of MAP kinases by calcium-dependent and calcium independent pathways. J. Biol. Chem. 267:1987619883.

10. Cobb, M. H., T. G. Boulton, and D. J. Robbins. 1991. Extracellular signal-regulated kinases: ERKs in progress. Cell Reg. 2:965-978.

11. Crews, C. M., A. Alessandrini, and R. L. Erikson. 1992. The primary structure of MEK, a protein kinase that phosphorylates the ERK gene product. Science 258:478-480.

12. de Vries-Smits, A. M. M., B. M. T. Burgering, S. J. Leevers, C. J. Marshall, and J. L. Bos. 1992. Involvement of p21ras in activation of extracellular signal-regulated kinase 2 . Nature (London) 357:602-604.

13. Gómez, N., and P. Cohen. 1991. Dissection of the protein kinase cascade by which nerve growth factor activates MAP kinases. Nature (London) 353:170-173.

14. Grynkiewicz, G., M. Poenie, and R. Y. Tsien. 1985. A new generation of $\mathrm{Ca}^{2+}$ indicators with greatly improved fluorescence properties. J. Biol. Chem. 260:3340-3450.

15. Gutierrez, L., A. I. Magee, C. J. Marshall, and J. F. Hancock. 1989. Post-translational processing of p21ras is two-step and involves carboxyl-methylation and carboxy-terminal proteolysis. EMBO J. 8:1093-1098.

16. Hoshi, M., E. Nishida, and H. Sakai. 1989. Characterization of a mitogen-activated $\mathrm{Ca}^{2+}$-sensitive microtubule-associated protein-2 kinase. Eur. J. Biochem. 184:477-486.

17. Howe, L. R., S. J. Leevers, N. Gómez, S. Nakielny, P. Cohen, and C. J. Marshall. 1992. Activation of the MAP kinase pathway by the protein kinase raf. Cell 71:335-342.

18. Izquierdo, M. J., J. Downward, J. D. Graves, and D. A. Cantrell. 1992. The role of protein kinase $C$ in T-cell antigen receptor regulation of $\mathrm{p} 21^{\text {ras }}$ : evidence that two $\mathrm{p} 21^{\text {ras }}$ regulatory pathways coexist in T cells. Mol. Cell. Biol. 12:3305-3312.

19. Kaplan, P. L., and B. Ozanne. 1983. Cellular responsiveness to growth factors correlates with a cell's ability to express the transformed phenotype. Cell 33:931-938.

20. Kazlauskas, A., and J. A. Cooper. 1988. Protein kinase C mediates platelet-derived growth factor-induced tyrosine phosphorylation of p42. J. Cell Biol. 106:1395-1402.

21. Kolch, W., G. Heidecker, G. Kochs, R. Hummel, H. Vahldl, H. Mischak, G. Finkenzeller, D. Marmé, and U. R. Rapp. 1993. Protein kinase $\mathrm{C} \alpha$ activates RAF-1 by direct phosphorylation. Nature (London) 364:249-252.

22. Kolch, W., G. Heidecker, P. Lloyd, and U. R. Rapp. 1991. Raf-1 protein kinase is required for growth of induced NIH 3T3 cells. Nature (London) 349:426-428.

23. Kosako, H., E. Nishida, and Y. Gotoh. 1993. cDNA cloning of MAP kinase kinase reveals kinase cascade pathways in yeast to vertebrates. EMBO J. 12:787-794.

24. Kyriakis, J. M., H. App, X.-F. Zhang, P. Banjeree, D. L. Brautigan, U. R. Rapp, and J. Avruch. 1992. Raf-1 activates MAP kinase kinase. Nature (London) 358:417-421.

25. L'Allemain, G., T. W. Sturgill, and M. J. Weber. 1991. Defective regulation of mitogen-activated protein kinase activity in a 3T3 cell variant mitogenically nonresponsive to tetradecanoyl phorbol acetate. Mol. Cell. Biol. 11:1002-1008.

26. Lange-Carter, C. A., C. M. Pleiman, A. M. Gardner, K. J. Blumer, and G. L. Johnson. 1993. A divergence in the MAP kinase regulatory network defined by MEK kinase and raf. Science 260:315-319.

27. Leevers, S. J., and C. J. Marshall. 1992. Activation of extracellular signal-regulated kinase, ERK2, by p21ras oncoprotein. EMBO J. 11:569-574.

27a.Maassen, J. A. Personal communication.
28. McCormick, F. 1993. How receptors turn Ras on. Nature (London) 363:15-16.

29. Medema, R. H., B. M. T. Burgering, and J. L. Bos. 1991 Insulin-induced p21ras activation does not require protein kinase $\mathrm{C}$, but a protein sensitive to phenylarsine oxide. J. Biol. Chem. 266:21186-21189.

30. Medema, R. H., A. M. M. de Vries-Smits, G. C. M. van der Zon, J. A. Maassen, and J. L. Bos. 1993. Ras activation by insulin and epidermal growth factor through enhanced exchange of guanine nucleotides on p21 ras. Mol. Cell. Biol. 13:155-162.

31. Moodie, S. A., B. M. Willumsen, M. J. Weber, and A. Wolfman. 1993. Complexes of ras.GTP with raf-1 and mitogen-activated protein kinase kinase. Science 260:1658-1661.

32. Muldoon, L. L., H. Enslen, K. D. Rodland, and B. E. Magun. 1991. Stimulation of $\mathrm{Ca}^{2+}$ influx by endothelin-1 is subject to negative feedback by elevated intracellular $\mathrm{Ca}^{2+}$. Am. J. Physiol. 260:C1273-C1281.

33. Niedel, J. E., and P. J. Blackshear. 1985. Protein kinase C. Recept. Biochem. Methodol. 7:47-88.

34. Nishizuka, Y. 1988. The molecular heterogeneity of protein kinase $\mathrm{C}$ and its implications for cellular regulation. Nature (London) 334:661-665

35. Payne, D. M., A. J. Rossomando, P. Martino, A. K. Erickson, J.-H. Her, J. Shananowitz, D. F. Hunt, M. J. Weber, and T. W. Sturgill. 1991. Identification of the regulatory phosphorylation sites in pp42/mitogen-activated protein kinase (MAP kinase). EMBO J. 10:885-892.

36. Peppelenbosch, M. P., L. G. J. Tertoolen, J. den Hertog, and S. W. de Laat. 1993. Epidermal growth factor activates calcium channels by phospholipase- $\mathrm{A}_{2} / 5$-lipoxygenase-mediated leukotriene $\mathrm{C}_{4}$ production. Cell 69:295-303.

37. Posada, J., and J. A. Cooper. 1992. Requirements for phosphorylation of MAP kinase during meiosis in Xenopus oocytes. Science 255:212-215.

38. Smith, M. R., S. J. DeGudicibus, and D. W. Stacey. 1986. Requirement for c-ras proteins during viral oncogene transformation. Nature (London) 320:540-543.

39. Sozeri, O., K. Vollmer, M. Liyanage, D. Frith, G. Kour, G. E. Mark, and S. Stabel. 1992. Activation of the c-raf protein kinase by protein kinase C phosphorylation. Oncogene 7:2259-2262.

40. Sturgill, T. W., and T. Wu. 1991. Recent progress in characterization of protein kinase cascades for phosphorylation of ribosomal protein S6. Biochem. Biophys. Acta 1092:350-357.

41. Szeberényi, J., H. Cai, and G. M. Cooper. 1990. Effect of a dominant inhibitory Ha-ras mutation on neuronal differentiation of PC12 cells. Mol. Cell. Biol. 10:5324-5332.

42. Thomas, G. 1992. MAP kinase by any other name smells just as sweet. Cell 68:3-6.

43. Thomas, S. M., M. DeMarco, G. D'Arcangelo, S. Halegoua, and J. S. Brugge. 1992. Ras is essential for nerve growth factor- and phorbol ester-induced tyrosine phosphorylation of MAP kinases. Cell 48:525-534.

44. Warne, P. H., P. R. Viciana, and J. Downward. 1993. Direct interaction of Ras and the amino-terminal region of Raf-1 in vitro. Nature (London) 364:352-355.

45. Wood, K. W., C. Sarnecki, T. M. Roberts, and J. Blenis. 1992. Ras mediates nerve growth factor receptor modulation of three signal-transducing protein kinases: MAP kinase, raf-1, and RSK. Cell 68:1041-1050.

46. Zhang, X.-F., J. Settleman, J. M. Kyriakis, E. Takeuchi-Suzuki, S. J. Elledge, M. S. Marshall, J. T. Bruder, U. R. Rapp, and J. A. Avruch. 1993. Normal and oncogenic p21 ${ }^{\text {ras }}$ proteins bind to the amino-terminal regulatory domain of c-Raf-1. Nature (London) 364:308-313 